\title{
Article \\ Preparation and Preliminary Evaluation of Silver-Modified Anodic Alumina for Biomedical Applications
}

\author{
Denitsa Kiradzhiyska ${ }^{1, *(\mathbb{D})}$, Nikolina Milcheva ${ }^{1, *(\mathbb{D})}$, Rositsa Mancheva ${ }^{1}$, Tsvetelina Batsalova ${ }^{2}$ (D), \\ Balik Dzhambazov ${ }^{2}$ (D) and Nikolay Zahariev ${ }^{3,4}$ (D)
}

1 Department of Chemical Sciences, Faculty of Pharmacy, Medical University of Plovdiv, 15A Vassil Aprilov blvd., 4000 Plovdiv, Bulgaria; r_manch@abv.bg

2 Department of Developmental Biology, Plovdiv University "Paisii Hilendarski", 24 Tsar Assen Str., 4000 Plovdiv, Bulgaria; tsvetelina@uni-plovdiv.bg (T.B.); balik@uni-plovdiv.net (B.D.)

3 Department of Pharmaceutical Sciences, Faculty of Pharmacy, Medical University of Plovdiv, 15A Vassil Aprilov blvd., 4000 Plovdiv, Bulgaria; nikolay.zahariev@mu-plovdiv.bg

4 Research Institute, Medical University of Plovdiv, 15A Vassil Aprilov blvd., 4000 Plovdiv, Bulgaria

* Correspondence: denitsa.kiradzhiyska@mu-plovdiv.bg (D.K.); nikolina.milcheva@mu-plovdiv.bg (N.M.)

Citation: Kiradzhiyska, D.; Milcheva, N.; Mancheva, R.; Batsalova, T.; Dzhambazov, B.; Zahariev, N. Preparation and Preliminary

Evaluation of Silver-Modified Anodic Alumina for Biomedical Applications. Metals 2022, 12, 51. https://doi.org/ $10.3390 /$ met12010051

Academic Editor: Manuel Aureliano

Received: 26 November 2021

Accepted: 24 December 2021

Published: 27 December 2021

Publisher's Note: MDPI stays neutral with regard to jurisdictional claims in published maps and institutional affiliations.

Copyright: (c) 2021 by the authors. Licensee MDPI, Basel, Switzerland. This article is an open access article distributed under the terms and conditions of the Creative Commons Attribution (CC BY) license (https:// creativecommons.org/licenses/by/ $4.0 /)$.

\begin{abstract}
The present study reports a specific method for preparation of silver-modified anodic alumina substrates intended for biomaterial applications. $\mathrm{Al}_{2} \mathrm{O}_{3}$ coatings were obtained by anodization of technically pure aluminum alloy in sulfuric acid electrolyte. Silver deposition into the pores of the anodic structures was carried out employing in situ thermal reduction for different time periods. The obtained coatings were characterized using scanning electron microscopy (SEM), potentiodynamic scanning after $168 \mathrm{~h}$ in $3.5 \% \mathrm{NaCl}$ solution and bioassays with human fibroblast and NIH/3T3 cell lines. The modified alumina substrates demonstrated better biocompatibility compared to the control anodic $\mathrm{Al}_{2} \mathrm{O}_{3}$ pads indicated by increased percent cell survival following in vitro culture with human and mouse fibroblasts. The Ag-deposition time did not affect considerably the biocompatibility of the investigated anodic layers. SEM analyses indicated that mouse NIH/3T3 cells and human fibroblasts adhere to the silver-coated alumina substrates retaining normal morphology and ability to form cell monolayer. Therefore, the present studies demonstrate that silver coating of anodic alumina substrates improves their biocompatibility and their eventual biomedical application.
\end{abstract}

Keywords: Ag/AAO substrates; biocompatibility; fibroblasts; scanning electron microscopy

\section{Introduction}

Nowadays, various combinations of materials are under in-depth investigations when creating medical devices. It is well known that the quintessential biomaterial has not yet been introduced into the medical practice. In this regard, surface modification of implants is considered to be the most promising method for preventing corrosion and promoting biocompatibility [1].

Aluminum (Al) is widely applicable in different technological fields owing to its mechanical properties, for example high tensile strength, good heat and electrical conductivity, low coefficients of friction and deformation, easy processing, etc. [2]. Due to its toxicity to living organisms $\mathrm{Al}$ has not been extensively studied as a potential material for production of medical devices [3]. However, the naturally formed in air oxide layer on aluminum and its alloys passivates the metal surface and interrupts any further interactions with the environment. There are studies stating that $\mathrm{Al}_{2} \mathrm{O}_{3}$ is an inert compound when introduced to biological systems [4]. Moreover, anodizing is commonly used electrochemical surface treatment resulting in a formation of anodic alumina oxide (AAO) with controllable thickness, porosity, morphology, etc. It is established that anodic films exhibit improved mechanical and anti-corrosive properties [5]. Further, these oxide layers can be additionally modified by deposition of different metals within their pores. There are various studies 
describing incorporation of $\mathrm{Pb}, \mathrm{Cd}, \mathrm{Cr}, \mathrm{Fe}, \mathrm{Au}, \mathrm{Co}, \mathrm{Cu}, \mathrm{Mn}, \mathrm{Ni}, \mathrm{Se}, \mathrm{Ag}, \mathrm{Te}, \mathrm{Zn}, \mathrm{Sn}$ on anodized aluminum substrates [6]. At the same time the use of noble metals, such as gold and silver when creating biomaterials, is a very prospective approach to enhance bioactive and antimicrobial properties $[7,8]$.

The increasing resistance of bacteria to commonly used antibiotics imposes extensive research activities in the field of new therapeutic agents with the aim to prevent or inhibit infectious diseases [9]. A prominent fact is that silver induces excellent inhibitory effect on different types of bacteria-P. aeruginosa, S. faecalis, S. aureus [10], M. luteus, E. coli, etc. [11], but at the same time nanosized silver can cause toxicity to liver and stem cells, human and mouse fibroblasts, as well as human carcinoma cells [12]. There are many investigations dealing with the dependency of silver biological activity and its size, shape, morphology, surface area, etc. [13]. Usually, the diameter of typical silver nanoparticles ranges from a few to dozen nm [8]. Various types of methods (physical, chemical, photochemical and biological) for their synthesis have been already reported [14]. However the resulting products in nanoform have different characteristic parameters. Therefore, they should be considered as different materials with non-identical mechanisms of action and resistance [13, 15]. Due to their unique physical and chemical properties silver nanoparticles have already been used as biosensors, cosmetics, and pharmaceutical products [16], in fillers, food packaging, wastewater treatment [14], catalysis, electronics, and photonics [17], cancer treatment [18]. When deposited and interacting with a matrix, these nanostructures can reveal new operating functions. For example, such combination of porous template and incorporated nanomaterial can be useful as antibacterial drug release carrier, in orthopedics, in dentistry, and other medical fields [19]. It is worth mentioning that the increased interest in utilizing alumina coatings for biomedical applications is related to their good wear and anticorrosive properties, low cost, improved surface functionalization, etc. [20].

In the present work, biological and anti-corrosive properties of silver-modified anodic films on the surface of technically pure aluminum alloy were investigated. For this purpose, the obtained combined layers were analyzed by scanning electron microscopy. The observations showed the presence of silver into the anodic alumina structures. The size of the deposited particles was above the nanoscale, which indicates aggregation of nanoparticles under the given conditions of in situ thermal reduction. The concentration of the silver deposits was determined using inductively coupled plasma optical emission spectroscopy (ICP-OES). The corrosion protective capabilities provided by the above mentioned modifications were studied using potentiodynamic scanning (PDS). Furthermore, in vitro biocompatibility assays with two fibroblast cell lines combined with light and scanning electron microscopy analyses were conducted to clarify the biological activity of the modified alumina substrates.

\section{Materials and Methods}

\subsection{Anodic Alumina Oxide Preparation}

All experimental procedures were performed with EN AW 1050A aluminum alloy with chemical composition corresponding to EN standard EN 573-3/485-2. The dimensions of the specimens were $20 \mathrm{~mm} \times 20 \mathrm{~mm} \times 0.5 \mathrm{~mm}$.

In order to remove accidental dirt and some defects, metal pads with working area of 8 $\mathrm{cm}^{2}$ were pre-treated by degreasing in acetone, pickling in diluted nitric acid $(1: 1 \mathrm{v} / \mathrm{v})$ and electropolishing in a mixture of concentrated perchloric acid and ethanol $(1: 4 \mathrm{v} / \mathrm{v})$ at constant voltage of $10 \mathrm{~V}$ for $3 \mathrm{~min}$. Then, the samples were anodized in $1.53 \mathrm{~mol} \mathrm{~L}^{-1} \mathrm{H}_{2} \mathrm{SO}_{4}$ at constant current density of $15 \times 10^{-3} \mathrm{~A} \mathrm{~cm}^{-2}$ at $20 \pm 2{ }^{\circ} \mathrm{C}$ for 30 or $60 \mathrm{~min}$. A two electrode cell was used with a lead plate as a counter electrode, placed symmetrically around the anode. After each operation, the samples are repeatedly washed with double distilled water and carefully dried. All solutions were prepared with analytical grade reagents. 


\subsection{Chemical Deposition of Silver}

Anodized aluminum substrates were immersed in a solution of $5 \mathrm{mM} \mathrm{AgNO}$ for different time periods ( 3 or $6 \mathrm{~min}$ ) at $96 \pm 1{ }^{\circ} \mathrm{C}$. The addition of a reducing agent is considered to be the start of the reaction. In the current work silver nitrate solutions were reduced by 0.1 wt. \% trisodium citrate $\left(\mathrm{Na}_{3} \mathrm{C}_{6} \mathrm{H}_{5} \mathrm{O}_{7}\right)$. Volume ratio of $\mathrm{Na}_{3} \mathrm{C}_{6} \mathrm{H}_{5} \mathrm{O}_{7}$ to $\mathrm{AgNO}_{3}$ was 1:10 [16]. Depending on the silver deposition time and respectively the amount of the incorporated particles, the color of the anode film changes to pale yellow.

Finally, in order to close up the pores of the Ag-containing oxide layers, the latter were soaked in boiling water at $96 \pm 1{ }^{\circ} \mathrm{C}$ for $25 \mathrm{~min}$. This method of simultaneously synthesis and deposition of silver nanoparticles followed by pore sealing of the layers was previously described [21].

\subsection{Silver Amount Determination}

The concentration of the deposited silver into the anodic films was determined by inductively coupled plasma optical emission spectroscopy (ICP-OES) using Prodigy 7 spectrometer (Teledyne Leeman Labs). For this purpose silver-modified anodic layers were dissolved in a mixture of concentrated nitric acid and water (1:1), at room temperature.

\subsection{Microstructure Characterization of the Silver-Modified Structures}

The as obtained Ag-doped anodic films were analyzed by scanning electron microscopy (Prisma ${ }^{\mathrm{TM}}$ E SEM by Thermo Fisher Scientific with an attachment for element analysis-EDX analyzer, Waltham, MA, USA).

\subsection{Electrochemical Analysis}

Potentiodynamic scanning (PDS) (performed by Universal Galvanostat/Potentiostat - AUTOLAB PG/STAT 30/2, product of Ecochemie, Kanaalweg, The Netherlands) was performed after $168 \mathrm{~h}$ of exposure to $3.5 \% \mathrm{NaCl}$ solution as model corrosive medium. $\mathrm{Ag} / \mathrm{AgCl} / 3 \mathrm{M} \mathrm{KCl}$ was used as a reference electrode and a platinum cylindrical mesh as a counter electrode. PDS curves were obtained from -100 to $1000 \mathrm{mV}$ against open circuit potential with a voltage sweep rate of $10 \mathrm{mV} \mathrm{s}^{-1}$. The measurements were performed with two identical samples of each type since the electrochemical behavior of anodized EN AW 1050 alloy has already been reported with good repeatability of the results [22].

\subsection{Cell Lines and In Vitro Cultivation Conditions}

Silver-modified alumina substrates biocompatibility was evaluated in vitro using murine and human fibroblasts: NIH/3T3 (ATCC CRL-1658)—an immortalized mouse embryonic cell line, and a finite human cell line established from preputium-derived fibroblasts. The cells were cultured in vitro in complete Dulbecco's modified Eagles's medium (DMEM), i.e. DMEM supplemented with $10 \%$ heat-inactivated fetal calf serum (FCS), $100 \mathrm{U} \mathrm{mL}^{-1}$ penicillin and $100 \mu \mathrm{g} \mathrm{mL} \mathrm{m}^{-1}$ streptomycin (all purchased from SigmaAldrich Inc., Merck KGaA, Darmstadt, Germany). The cultures were maintained at $37^{\circ} \mathrm{C}$, $5 \% \mathrm{CO}_{2}$ /atmospheric air mixture and high humidity. Before the biocompatibility evaluations the cells were grown in $75 \mathrm{~cm}^{2}$ culture flasks (TPP, Trasadingen, Switzerland) and subcultured at $80 \%$ confluency. In brief, cell monolayers were washed with Dulbecco's modified phosphate buffered saline (DPBS) (Sigma-Aldrich Inc., Merck KGaA, Darmstadt, Germany) and detached using $0.2 \%$ trypsin/0.53 mM EDTA buffer solution. The concentration of viable cells in the resulting suspensions was determined by the Trypan blue assay [23]. A total $50 \mu \mathrm{L}$ cell suspension were mixed with equal volume of $0.4 \%$ Trypan blue solution (Sigma-Aldrich Inc., Merck KGaA, Darmstadt, Germany), loaded on a Burker chamber (Boeco, Hamburg, Germany) and counted using Ceti Max III compound microscope (Medline scientific, Oxon, UK). Then, concentration of live cells per $\mathrm{mL}$ was calculated, the suspensions containing detached NIH/3T3 and human fibroblasts were diluted to appropriate concentration and new cultures were established. 


\subsection{Biocompatibility Evaluations}

Anodized aluminum substrates and silver-doped alumina pads were placed on the bottom of separate wells in 6-well culture plates (TPP, Trasadingen, Switzerland). After that, $1 \times 10^{5}$ cells $\mathrm{mL}^{-1} \mathrm{NIH} / 3 \mathrm{~T} 3$ and human fibroblasts $(2 \mathrm{~mL}$ cell suspension per well) were seeded on the plates containing alumina test-substrates and cultured for $48 \mathrm{~h}$. Control cells were grown for the same time period in wells containing a glass coverslip. The size of the glass substrate corresponded to the size of the analyzed alumina pads. After the end of the incubation period the test-substrates and control glass coverslips were removed from the culture plates and 3-(4,5-dimethylthiazol-2-yl)-2,5-diphenyltetrazolium bromide (MTT) solution was added to the cell culture medium to a final concentration of $0.5 \mathrm{mg} \mathrm{mL}^{-1}$.

The MTT assay principle was initially described by Mossman [24]. In the present experiments, the MTT tests were performed in accordance to the methodology published by Edmondson et al. [25]. In brief, the cells were incubated in MTT containing medium for $2 \mathrm{~h}$ under standard conditions $\left(37^{\circ} \mathrm{C}, 5 \% \mathrm{CO}_{2}\right.$ and high humidity). After that, the cells were washed with pre-warmed $\left(37^{\circ} \mathrm{C}\right)$ DPBS and $1 \mathrm{~mL}$ dimethyl sulfoxide (DMSO) was added to each well of the culture vessels. After $15 \mathrm{~min}$ incubation with DMSO at $37^{\circ} \mathrm{C}$, absorbance at $570 \mathrm{~nm}$ was measured using Synergy-2 reader (BioTek, Winooski, VT, USA). Percent cell survival was determined based on the data for cells co-cultured with alumina substrates and control cells. All substrates were tested in duplicates.

\subsection{Cell Morphology Analysis}

Cellular morphology and culture monolayer integrity after $48 \mathrm{~h}$ co-cultivation with alumina test-substrates were evaluated using a standard inverted microscope Inverso (Medline Scientific, Oxon, UK) and Si-3000 high definition digital camera (Medline Scientific, Oxon, UK).

$\mathrm{NIH} / 3 \mathrm{~T} 3$ and human fibroblasts attached to the surface of alumina specimens were observed by scanning electron microscope (Prisma ${ }^{\mathrm{TM}}$ E SEM by Thermo Fisher Scientific). Prior to the SEM evaluations, the cells were seeded on test-substrates placed in 6-well plates (TPP, Trasadingen, Switzerland) and cultured for $48 \mathrm{~h}$ as described in the previous subsection. Then, alumina pads and control glass coverslips were removed from the plates and processed as described by Osahor et al. [26]. The specimens were washed twice in pre-warmed $\left(37^{\circ} \mathrm{C}\right)$ DPBS and fixed with $2.5 \%$ glutaraldehyde for 30 min at $37^{\circ} \mathrm{C}$. After that, the cells were immediately subjected to alcohol dehydration using $25 \%, 40 \%, 60 \%$, $80 \%, 90 \%$ and $100 \%$ ethanol gradient treatment for $15 \mathrm{~min}$ for each concentration. The specimens were dried in a simple desiccator for $30 \mathrm{~min}$.

\subsection{Statistics}

Statistics was calculated based on analysis of variance (ANOVA) using the StatView software version 5.0 (SAS Institute, Cary, NC, USA). Significant differences between data from control anodic alumina substrates and silver-modified samples were determined by Fisher's PLSD method. Estimated $p$ values lower than 0.05 were considered statistically significant.

\section{Results and Discussion}

All set of samples used in the current work and the corresponding treatment procedures are described in Table 1.

It is considered that cell growth, cytotoxicity, genotoxicity and biocompatibility depend on the morphological characteristics such as size, shape, surface charge, concentration, distribution of particles, exposure time and cell type $[27,28]$. In order to determine the concentration of deposited Ag particles into the anodized alumina layers, all samples were submitted to induction coupled plasma optical emission spectroscopy (ICP-OES) and the acquired quantitative data are graphically represented in Figure 1. As expected, the $\mathrm{Ag}$ amount is proportional to the silver deposition time. It was also found that the concentration of $\mathrm{Ag}$ is higher at the anodic films formed in the acid electrolyte for $60 \mathrm{~min}$. 
Table 1. Sample groups and their abbreviation used in the manuscript.

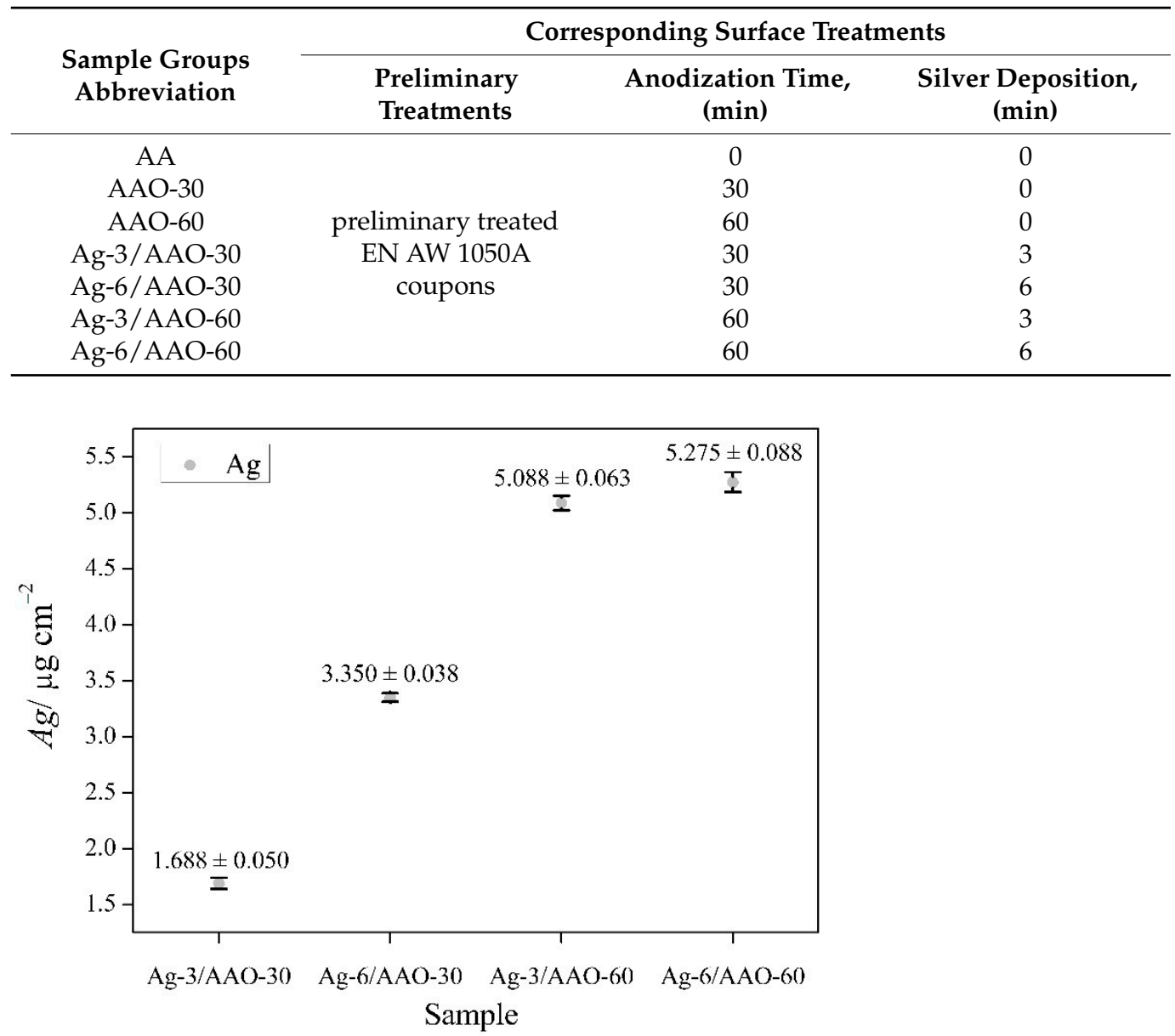

Figure 1. Correlation between the deposited Ag content, silvering time and anodization time periods. The mean value of $\mathrm{Ag}$ content $\left(\mu \mathrm{g} \mathrm{cm}^{-2}\right)$ and standard deviation (SD) of it are presented at the figure. All analysis were performed three times $(n=3)$.

The images in Figure 2 show potentiodynamic polarization curves of different metal pads of chosen sample groups. As it can be seen, the bare aluminum coupons suffer uniform corrosion attack. At the same time, the curves of anodized samples (with or without silver deposits) have almost horizontal branches, revealing good passivation properties by the thick alumina layers. In Table 2 the obtained experimental results of the PDS analysis are summarized. The corrosion potentials of all samples underwent anodic oxidation are shifted to more positive values. This fact is consequence of the modifications of the surface chemical composition, as proposed in Kozhukharov et al. [22]. Significant difference of the polarization resistance and corrosion current density values was observed only between the untreated aluminum coupons and all AAO samples. The presence of silver particles in these layers does not significantly change the barrier ability of the combined films. 

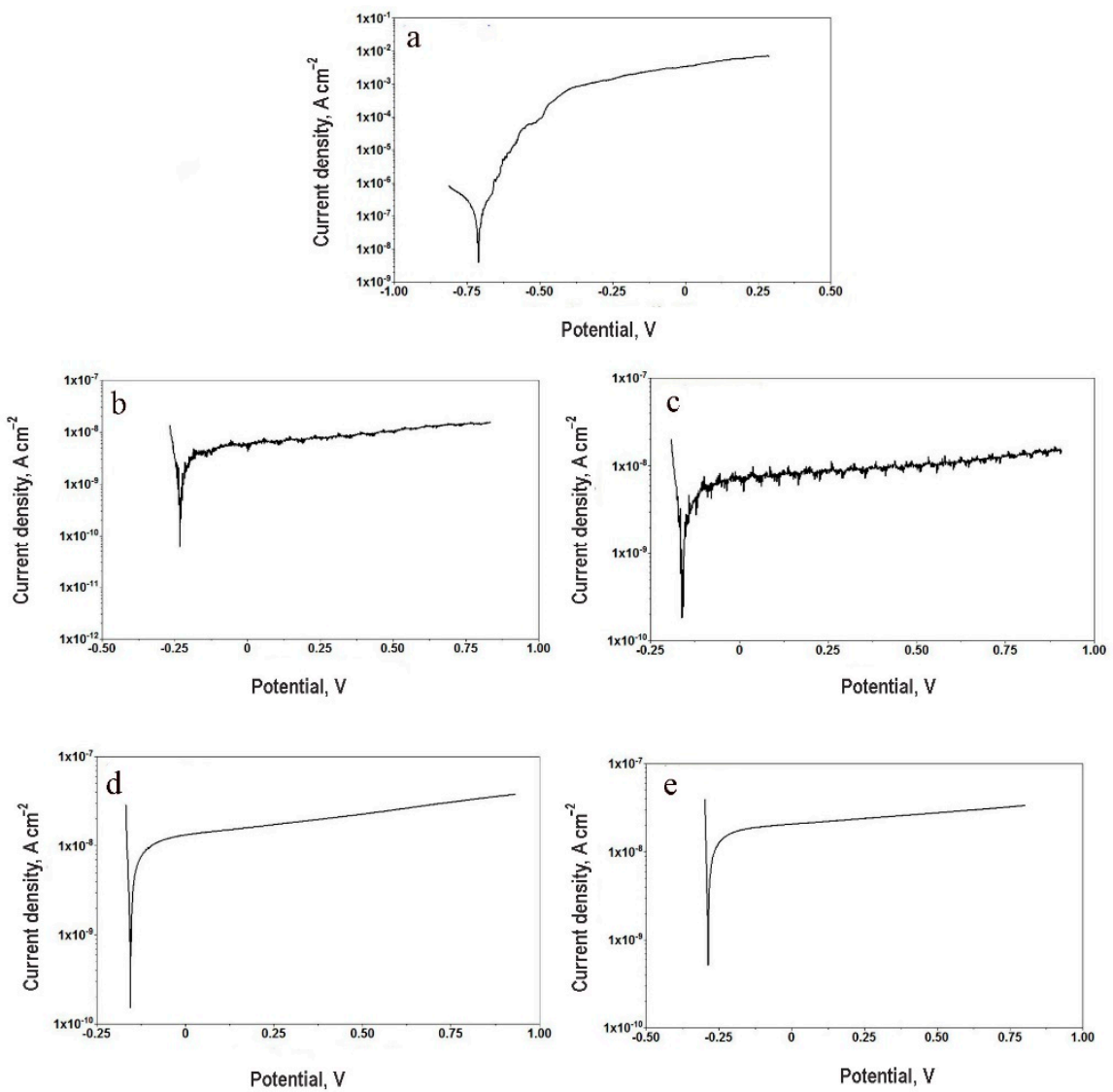

Figure 2. Potentiodynamic curves acquired after $168 \mathrm{~h}$ for (a) AA coupons, (b) AAO-30, (c) AAO-60, (d) Ag-6/AAO-30, (e) Ag-6/AAO-60.

Table 2. A summary of PDS data results, acquired from Tafel slope analysis.

\begin{tabular}{|c|c|c|c|}
\hline \multirow{2}{*}{ Sample Groups } & Corrosion Potential & $\begin{array}{l}\text { Polarization } \\
\text { Resistance }\end{array}$ & $\begin{array}{c}\text { Corrosion Current } \\
\text { Density }\end{array}$ \\
\hline & $\begin{array}{c}E_{\text {corr }} /(\mathrm{mV}) \text { vs. } \\
\mathrm{Ag} / \mathrm{AgCl}\end{array}$ & $\begin{array}{c}R_{\mathrm{p}} \\
\left(\mathrm{k} \Omega \mathrm{cm}^{-2}\right)\end{array}$ & $\begin{array}{c}I_{\text {corr }} \\
\left(\mathrm{A} \mathrm{cm}^{-2}\right)\end{array}$ \\
\hline AA & $-720 \pm 11$ & $83.01 \pm 12$ & $(4.7 \pm 0.6) \times 10^{-8}$ \\
\hline AAO-30 & $-231 \pm 45$ & $7862 \pm 900$ & $(2.3 \pm 1.1) \times 10^{-10}$ \\
\hline AAO-60 & $-162 \pm 36$ & $4207 \pm 517$ & $(1.8 \pm 1.1) \times 10^{-10}$ \\
\hline Ag-3/AAO-30 & $-155 \pm 28$ & $6980 \pm 723$ & $(1.0 \pm 0.9) \times 10^{-10}$ \\
\hline Ag-6/AAO-30 & $-288 \pm 57$ & $7000 \pm 657$ & $(1.4 \pm 1.0) \times 10^{-10}$ \\
\hline Ag-3/AAO-60 & $-720 \pm 11$ & $83.01 \pm 12$ & $(4.7 \pm 0.6) \times 10^{-8}$ \\
\hline Ag-6/AAO-60 & $-231 \pm 45$ & $7862 \pm 900$ & $(2.3 \pm 1.1) \times 10^{-10}$ \\
\hline
\end{tabular}

\subsection{Scanning Electron Microscope Observations}

In order to examine the morphological futures of the silver doped alumina films systematic SEM observations of all types of silver modified probes were performed. The topological and compositional characteristics of similar anodic alumina coatings are investigated in detail. The presence of equally distributed pits and cavities on the anodized specimens has already been described [29]. These imperfections of the alumina films are formed on sites of heavier intermetallic inclusions, which are typical contaminants for the technically pure aluminum alloy. On Figure 3 micrographs of Ag-doped anodic oxide surfaces at magnification $\times 20,000$ are presented. As it can be seen, the performance of the anodic processes at these conditions results in the formation of $\mathrm{Al}_{2} \mathrm{O}_{3}$ with irregular distribution and structure of its pores. More interesting is the fact that depending on the 
silver deposition time and the following sealing procedure the final Ag/ AAO morphology is unique. Silver particles with different size (over nanoscale) are not evenly distributed on the alumina surfaces. The chemical compositions of specimens were investigated by the attachment for element analysis-EDX analyzer.
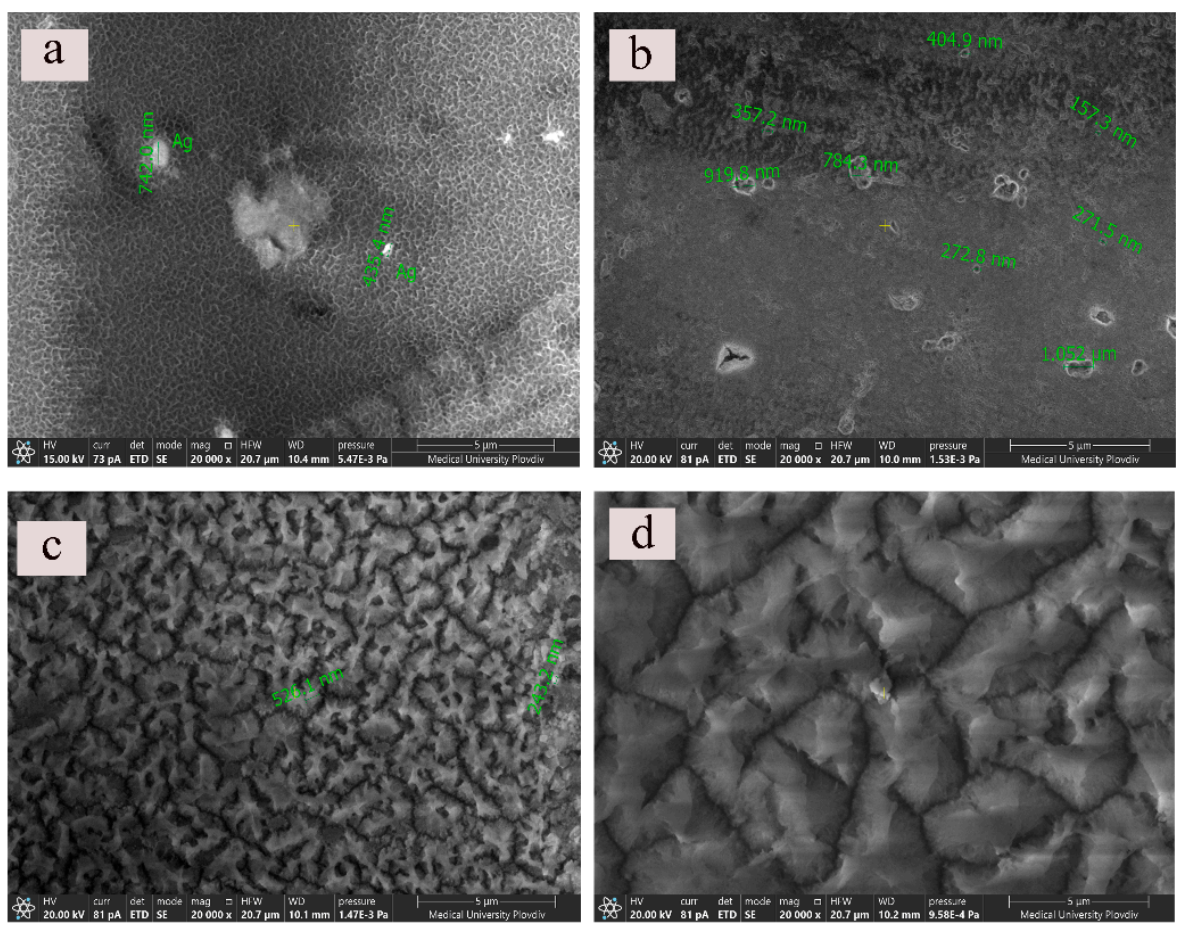

Figure 3. SEM micrographs of (a) Ag-6/AAO-30, (b) Ag-6/AAO-30, (c) Ag-3/AAO-60 (d) Ag6/AAO-60 at $\times 20,000$ magnification.

In Figure $3 \mathrm{a}$ it can be seen the irregular porous structure of the oxide, individual silver particles and agglomerates. In Figure $3 b$, probably as a result of the longer silvering time (6 min), the Ag particles are located on the edges of the pits and cavities of the alumina. In addition, the oxide film looks less porous. Presumably, the extended silver deposition time in a combination with the sealing treatment of the sample results in the production of crystalline hydrate phase which fills the pores of the oxide film. Hydrothermal sealing of anodized aluminum at temperatures above $95{ }^{\circ} \mathrm{C}$ is previously reported to promote hydration of porous oxides and barrier layers, producing boehmite $(\gamma-\mathrm{AlO}(\mathrm{OH}))$ [30]. More obvious this can be seen in Figure $3 \mathrm{c}$ where the anodic film formation is extended to $60 \mathrm{~min}$. In Figure 3d (60 min anodization and 6 min silver deposition time) the surface morphology of the alumina layer is substantially different. There is a total lack of the porous skeleton of the $\mathrm{Al}_{2} \mathrm{O}_{3}$ probably due to the filling of the pore mouths with hydrated products like boehmite, $\mathrm{Al}_{2}\left(\mathrm{SO}_{4}\right)_{3}[30]$.

It should be pointed out that for better detection of the silver particles with the EDX analyzer detailed observations of the top-view of the surfaces at different magnifications were performed. In Figure 4 a micrograph of a specimen corresponding to Ag-6/AAO-60 at $\times 35,000$ is presented. It can be seen that silver particles are incorporated in the hydrated porous structure. 


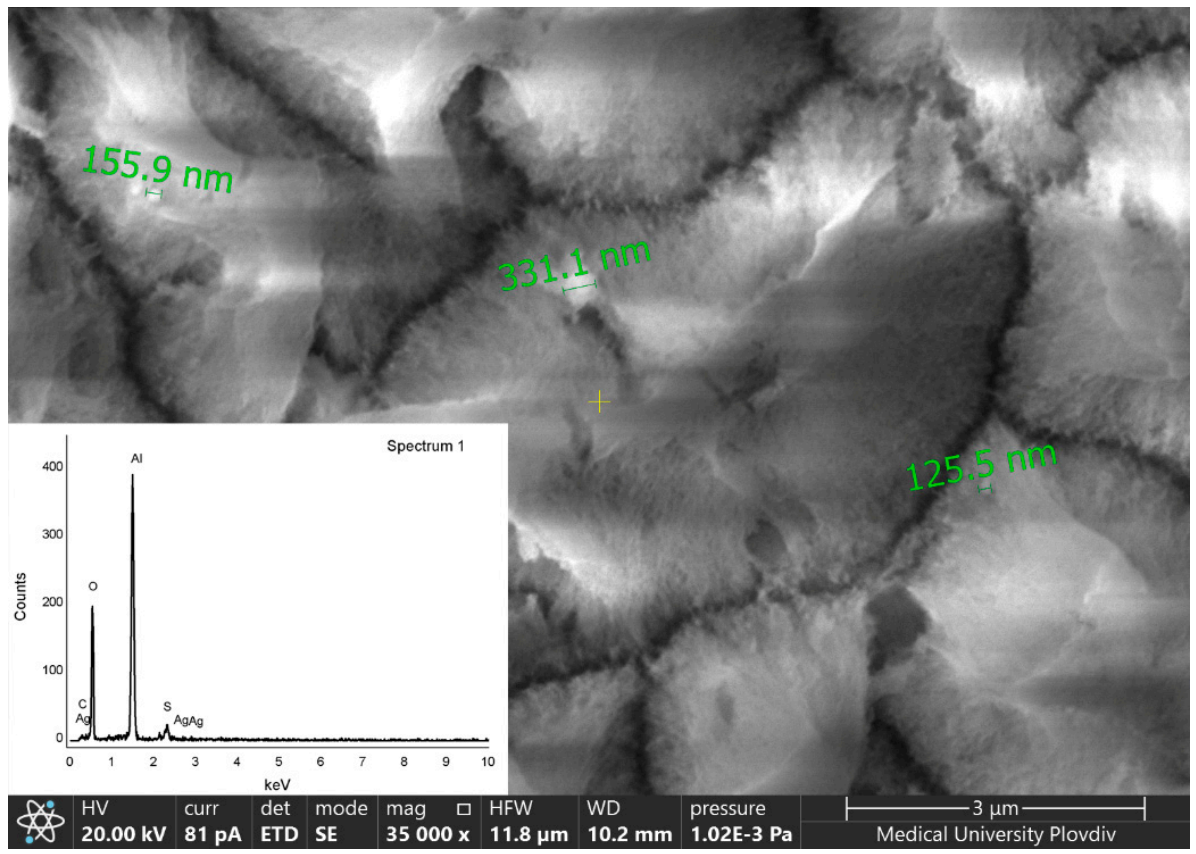

Figure 4. SEM image of Ag-6/AAO-60 specimen at magnification $\times 35,000$.

\subsection{Biocompatibility of Silver-Modified Alumina Substrates}

$\mathrm{NIH} / 3 \mathrm{~T} 3$ cells and human dermal fibroblasts were co-cultured for $48 \mathrm{~h}$ with silverdoped alumina pads and control anodized alumina specimens without silver modification. After the end of the incubation period cell survival was determined by MTT assays. Figure 5 represents the obtained results. In accordance with our previous findings [27] NIH/3T3 cells demonstrated higher sensitivity to anodic alumina and silver-modified alumina substrates compared to human fibroblasts. The two specimens with anodized for 30 or $60 \mathrm{~min}$ alumina film showed the lowest cell survival level. A statistically significant difference was present between anodized alumina samples and the silver-doped substrates when co-cultured with the mouse fibroblast cell line (Figure $5 a, b)$. These results demonstrate that the generated silver layers on AAO-30 and AAO-60 substrates improved their biocompatibility when tested with NIH/3T3 cells. The same tendency was demonstrated by human fibroblasts (Figure 5c,d) confirming the biocompatibility of silver-doped samples. The cells were not affected significantly by co-cultivation with AAO-30 and AAO-60 samples-the calculated cell survival level was approximately $90 \%$. However, when co-cultured with silver-modified alumina substrates, human fibroblasts survival was higher, even similar to the control cells co-cultured with a glass substrate. These results suggest that silver modification enhances fibroblast cell survival rates when co-cultured with anodic alumina pads. It could be assumed that these positive effects are induced by changes in the substrate surface. Silver particles incorporate in the porous hydrated structure of the pads (Figure 4) and thus, affect their roughness and possibly improve cellular adhesion and survival. Additional experiments are needed to confirm this hypothesis. AAO-30 and AAO-60 specimens doped with silver for 3 and $6 \mathrm{~min}$ did not show significant difference in survival of both NIH/3T3 and human fibroblasts. Although SEM analyses indicated surface differences between AAO-30 and AAO-60 specimens doped with silver for 3 and 6 min cell survival levels did not show significant variance. It could be suggested that silver modification eliminates sites of intermetallic inclusions/imperfections of anodic alumina substrates independent of time for deposition ( 3 or $6 \mathrm{~min}$ ), which leads to improved cell survival. 

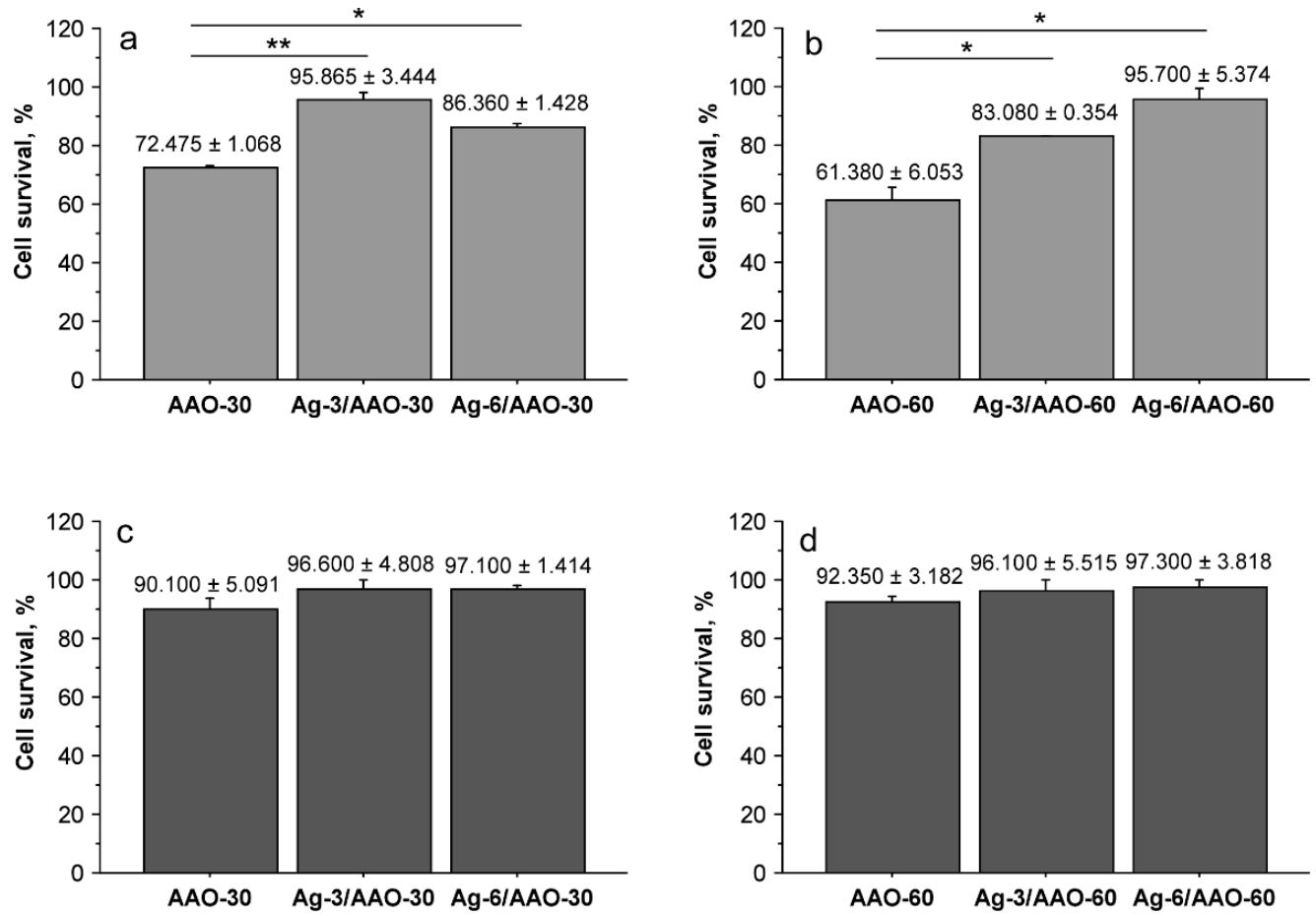

Figure 5. Cell survival levels determined after $48 \mathrm{~h}$ in vitro culture of NIH/3T3 cells (a), (b) and human fibroblasts (c), (d) with anodized alumina and silver-modified alumina substrates. All samples were tested in duplicates $(n=2)$. Figure bars represent mean \pm standard error of the mean and $\pm S D$ is indicated for each sample. ${ }^{*}$ Indicates $p<0.05,{ }^{* *} p<0.01$.

To support the data from MTT assays, light microscopy observations were performed. As shown on Figure 6 NIH/3T3 cells (Figure 6a) and human fibroblasts (Figure 6b) retained normal morphology, as well as ability to proliferate and form integral monolayer during co-culture with silver-modified alumina specimens. These findings confirm the high cell survival rates detected by the colorimetric assays. In addition, we were interested to find whether the cells are able to attach to the alumina substrates. Therefore, SEM analyses were performed. They revealed that $\mathrm{NIH} / 3 \mathrm{~T} 3$ and human fibroblasts adhere to both AAO (data not shown) and silver-doped AAO pads (Figure 6c,d). The cells displayed typical morphology that could be observed only after characteristic reorganization of the cytoskeleton during the experiment, formation of specific cellular protrusions and focal adhesions to the substrate followed by stable attachment. Moreover, SEM pictures showed individual rounded cells with discrete contact to the substrate. Generally, they were located above the plane of the layer formed by the majority of attached cells with characteristic morphology. Such position and the spherical form of the cells indicate a proliferative phenotype. The presence of mitotic cells on the silver-modified substrates proves further the biocompatibility of the tested materials. These findings show that both mouse and human fibroblasts are able to attach to the test-substrates. Moreover, as shown on Figure $6 \mathrm{e}, \mathrm{f}$ the cells develop and proliferate giving rise to a stable monolayer on the surface of silver-modified alumina specimens. 

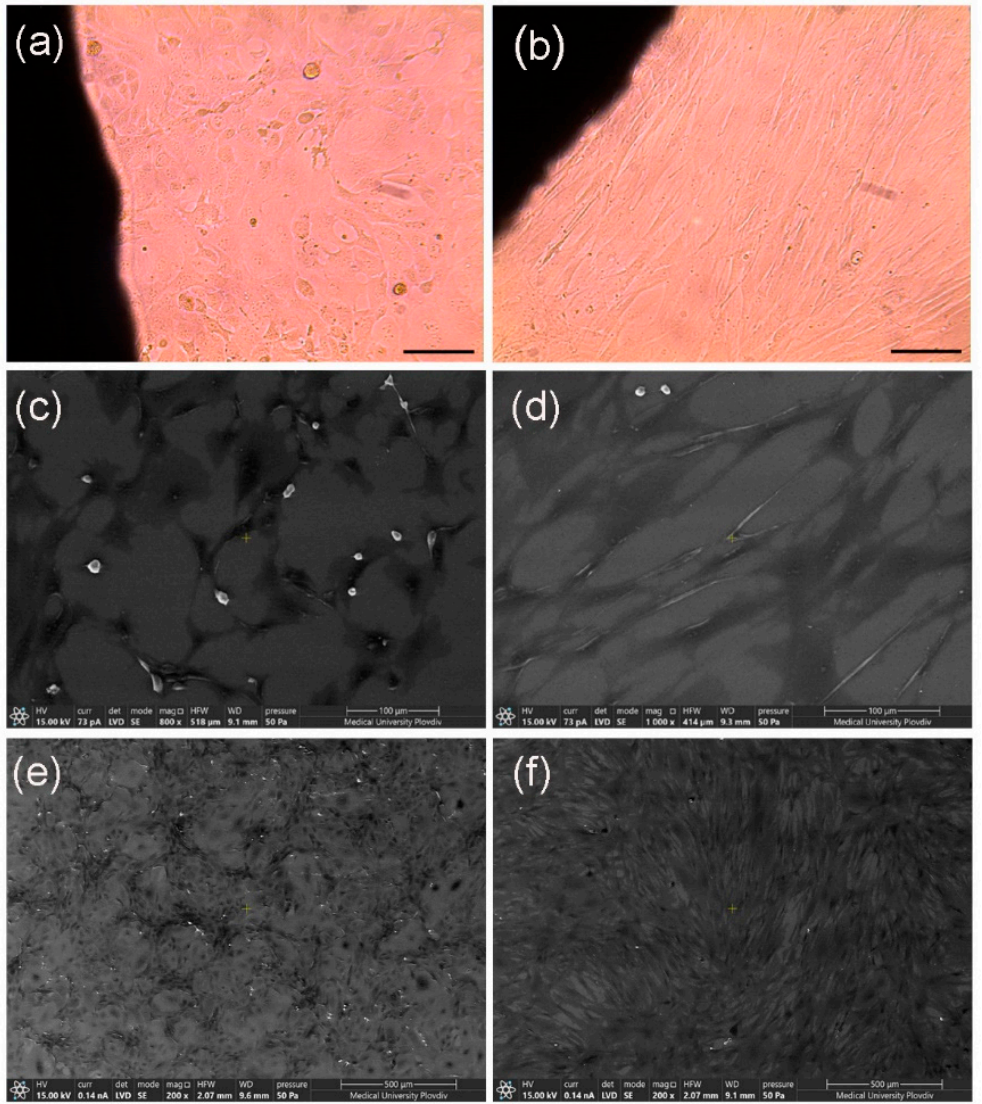

Figure 6. Light $(\mathbf{a}, \mathbf{b})$ and scanning electron microscopy $(\mathbf{c}-\mathbf{f})$ pictures of $\mathrm{NIH} / 3 \mathrm{~T} 3(\mathbf{a}, \mathbf{c}, \mathbf{e})$ and human fibroblasts $(\mathbf{b}, \mathbf{d}, \mathbf{f})$ co-cultured with silver-modified alumina substrates.

\section{Conclusions}

The present work demonstrates the biocompatibility of silver-modified anodic alumina pads based on in vitro assays with mouse NIH/3T3 and human fibroblasts. The mouse cell cultures demonstrated higher sensitivity to all anodic layers. However, when co-cultured with silver-modified AAO films, the cell survival levels of the two cell lines were sufficient. The concentration of the deposited silver particles did not affect these levels. The cell ability to attach to the surface of the samples was proven by scanning electron microscopy. SEM analyses were also performed in order to examine the morphological characteristics of the silver-modified layers. Depending on the Ag deposition time and the hydrothermal sealing procedure the resulting morphology of each specimen type was unique. Finally, regardless the structural differences all AAO layers (underwent or not silver modification) demonstrated good barrier ability in potentiodynamic polarization studies.

Author Contributions: Conceptualization, D.K., N.M. and T.B.; Formal analysis, D.K., T.B. and N.Z.; Funding acquisition, D.K. and N.M.; Investigation, D.K., T.B., N.Z. and N.M.; Methodology, D.K., N.M., R.M., B.D. and T.B.; Project administration, T.B. and D.K.; Software, D.K.; Supervision, D.K., N.M., T.B., R.M. and B.D.; Validation, D.K. and N.M.; Visualization, D.K. and N.M.; Writing—original draft, B.D., R.M., D.K. and T.B.; Writing—review \& editing, D.K., B.D., R.M., T.B. and N.M. All authors have read and agreed to the published version of the manuscript.

Funding: The authors would like to thank the Medical University of Plovdiv for financial support.

Data Availability Statement: The datasets used and analyzed during the current study are available from the corresponding author on reasonable request. All data are in the form of tables and figures. 
Conflicts of Interest: The authors declare that there are no conflicts of interest regarding the publication of this paper. The funders had no role in the design of the study; in the collection, analyses, or interpretation of data; in the writing of the manuscript, or in the decision to publish the results.

\section{References}

1. Manivasagam, G.; Dhinasekaran, D.; Rajamanickam, A. Biomedical Implants: Corrosion and Its Prevention-A Review. Recent Patents Corros. Sci. 2010, 2, 40-54. [CrossRef]

2. Polmear, I.; StJohn, D.; Nie, J.-F.; Qian, M. (Eds.) Wrought Aluminium Alloys. In Light Alloys; Butterworth-Heinemann: Oxford, UK, 2017; pp. 157-263. [CrossRef]

3. Langley, A.; Dameron, C.T. Modern Metal Implant Toxicity and Anaesthesia. Australas. Anaesth. 2015, 57-65. [CrossRef]

4. Christel, P.; Meunier, A.; Dorlot, J.M.; Crolet, J.M.; Witvoet, J.; Sedel, L.; Boutin, P. Biomechanical Compatibility and Design of Ceramic Implants for Orthopedic Surgery. Ann. N. Y. Acad. Sci. 1988, 523, 234-256. [CrossRef] [PubMed]

5. Yasakau, K.A.; Zheludkevich, M.L.; Ferreira, M.G.S. Role of Intermetallics in Corrosion of Aluminum Alloys. Smart Corrosion Protection. In Intermetallic Matrix Composites; Mitra, R., Ed.; Elsevier: Amsterdam, The Netherlands, 2018; pp. 425-462. [CrossRef]

6. Tomassi, P.; Nanostructures, Z.B. Aluminum Anodic Oxide AAO as a Template for Formation of Metal Nanostructures. In Electroplating of Nanostructures; Mahmood, A., Ed.; InTech: London, UK, 2015; pp. 75-102. [CrossRef]

7. Darouiche, R.O. State-Of-The-Art Clinical Anti-Infective Efficacy of Silver-Coated Medical Prostheses. Epidemiology 2011, 29, 1371-1377. [CrossRef]

8. Aina, V.; Cerrato, G.; Martra, G.; Bergandi, L.; Costamagna, C.; Ghigo, D.; Malavasi, G.; Lusvardi, G.; Menabue, L. GoldContaining Bioactive Glasses: A Solid-State Synthesis to Produce Alternative Biomaterials for Bone Implantations. J. R. Soc. Interface 2013, 10, 20121040. [CrossRef] [PubMed]

9. Hauser, A.R.; Mecsas, J.; Moir, D.T. Beyond Antibiotics: New Therapeutic Approaches for Bacterial Infections. Clin. Infect. Dis. 2016, 63, 89-95. [CrossRef]

10. Chi, G.J.; Yao, S.W.; Fan, J.; Zhang, W.G.; Wang, H.Z. Antibacterial Activity of Anodized Aluminum with Deposited Silver. Surf. Coatings Technol. 2002, 157, 162-165. [CrossRef]

11. Jagminas, A.; Žalnèravičius, R.; Rėza, A.; Paškevičius, A.; Selskienè, A. Design, Optical and Antimicrobial Properties of Extremely Thin Alumina Films Colored with Silver Nanospecies. Dalt. Trans. 2015, 44, 4512-4519. [CrossRef] [PubMed]

12. Marambio-Jones, C.; Hoek, E.M.V. A Review of the Antibacterial Effects of Silver Nanomaterials and Potential Implications for Human Health and the Environment. J. Nanoparticle Res. 2010, 12, 1531-1551. [CrossRef]

13. Kędziora, A.; Speruda, M.; Krzyżewska, E.; Rybka, J.; Łukowiak, A.; Bugla-Płoskońska, G. Similarities and Differences between Silver Ions and Silver in Nanoforms as Antibacterial Agents. Int. J. Mol. Sci. 2018, 19, 444. [CrossRef] [PubMed]

14. Haider, A.; Kang, I.-K. Preparation of Silver Nanoparticles and Their Industrial and Biomedical Applications: A Comprehensive Review. Adv. Mater. Sci. Eng. 2015, 2015, 1-15. [CrossRef]

15. Martínez-Castañón, G.A.; Niño-Martínez, N.; Martínez-Gutierrez, F.; Martínez-Mendoza, J.R.; Ruiz, F. Synthesis and Antibacterial Activity of Silver Nanoparticles with Different Sizes. J. Nanoparticle Res. 2008, 10, 1343-1348. [CrossRef]

16. Rashid, M.U.; Bhuiyan, M.K.H.; Quayum, M.E. Synthesis of Silver Nano Particles (Ag-NPs) and Their Uses for Quantitative Analysis of Vitamin C Tablets. Dhaka Univ. J. Pharm. Sci. 2013, 12, 29-33. [CrossRef]

17. Guzmán, M.G.; Dille, J.; Godet, S. Synthesis of Silver Nanoparticles by Chemical Reduction Method and Their Antibacterial Activity. Int. J. Mater. Metall. Eng. 2008, 2, 91-98. [CrossRef]

18. Kulkarni, N.; Muddapur, U. Biosynthesis of Metal Nanoparticles: A Review. J. Nanotechnol. 2014, 2014. [CrossRef]

19. Thorat, S.; Diaspro, A.; Scarpellini, A.; Povia, M.; Salerno, M. Comparative Study of Loading of Anodic Porous Alumina with Silver Nanoparticles Using Different Methods. Materials 2013, 6, 206-216. [CrossRef] [PubMed]

20. Toccafondi, C.; Dante, S.; Reverberi, A.P.; Salerno, M. Biomedical Applications of Anodic Porous Alumina. Curr. Nanosci. 2015, 11, 572-580. [CrossRef]

21. Pornnumpa, N.; Jariyaboon, M. Antibacterial and Corrosion Resistance Properties of Anodized AA6061 Aluminum Alloy. Eng. J. 2019, 23, 171-181. [CrossRef]

22. Kozhukharov, S.; Girginov, C.; Kiradzhiyska, D.; Tsanev, A.; Avdeev, G. Evaluation of the Electrochemical Performance of Ag Containing AAO Layers after Extended Exposure to a Model Corrosive Medium. J. Electrochem. Sci. Eng. 2020, 10, 317-334. [CrossRef]

23. Strober, W. Trypan Blue Exclusion Test of Cell Viability. Curr. Protoc. Immunol. 2015, 111, A3.B.1-A3.B.3. [CrossRef] [PubMed]

24. Mosmann, T. Rapid Colorimetric Assay for Cellular Growth and Survival: Application to Proliferation and Cytotoxicity Assays. J. Immunol. Methods 1983, 65, 55-63. [CrossRef]

25. Edmondson, J.M.; Armstrong, L.S.; Martinez, A.O. A Rapid and Simple MTT-Based Spectrophotometric Assay for Determining Drug Sensitivity in Monolayer Cultures. J. Tissue Cult. Methods 1988, 11, 15-17. [CrossRef]

26. Osahor, A.; Deekonda, K.; Lee, C.-W.; Sim, E.U.-H.; Radu, A.; Narayanan, K. Rapid Preparation of Adherent Mammalian Cells for Basic Scanning Electron Microscopy (SEM) Analysis. Anal. Biochem. 2017, 534, 46-48. [CrossRef]

27. Kiradzhiyska, D.; Batsalova, T.; Dzhambazov, B.; Mancheva, R. In Vitro Biocompatibility Evaluation of Anodic Alumina Substrates with Electrochemically Embedded Silver. Rev. Chim. 2020, 71, 81-88. [CrossRef] 
28. Zhang, X.-F.; Shen, W.; Gurunathan, S. Silver Nanoparticle-Mediated Cellular Responses in Various Cell Lines: An in Vitro Model. Int. J. Mol. Sci. 2016, 17, 1603. [CrossRef]

29. Kozhukharov, S.; Girginov, C.; Tsanev, A.; Petrova, M. Elucidation of the Anodization and Silver Incorporation Impact on the Surface Properties of AA1050 Aluminum Alloy. J. Electrochem. Soc. 2019, 166, C231. [CrossRef]

30. Ofoegbu, S.U.; Fernandes, F.A.O.; Pereira, A.B. The Sealing Step in Aluminum Anodizing: A Focus on Sustainable Strategies for Enhancing Both Energy Efficiency and Corrosion Resistance. Coatings 2020, 10, 226. [CrossRef] 